Rev. Biol. Trop., 47(1-2): 245-249, 1999

www.ucr.ac.cr www.ots.ac.cr www.ots.duke.edu

\title{
A technique for extraction and Thin Layer Chromatography visualization of fecal bile acids applied to neotropical felid scats
}

\author{
Ada Virginia Cazón Narvaez and Silvia Susana Sühring \\ Facultad de Ciencias Naturales, Universidad Nacional de Salta, Buenos Aires 177 (4400) Salta, Argentina \\ Fax: 0054-387-4255455, e-mail: cazon@ ciunsa.edu.ar suhring@unsa.edu.ar \\ Received 27-V-1998. Corrected 17-XI-1998. Accepted 27-XI-1998
}

\begin{abstract}
Fecal bile acid patterns have been used successfully to identify scats. Neotropical felid scats are capable of this biochemical identification because they present low concentrations of plant pigments that would interfere in fecal bile acids detection. However, neotropical felid scats have poor quantities of bile acids, so we developed in this work a proper technique for their extraction, visualization and determination. Twenty eighth feces of seven different felid species, collected from Zoological and Wildlife Parks, were dried and pulverized. The procedure for analyzing feces is: Take one $\mathrm{g}$ of pulverized feces and shake for $3 \mathrm{hr}$ at room temperature in $20 \mathrm{ml}$ benzene : methanol; filter and evaporate to $5 \mathrm{ml}$. Spot on TLC plate and develop in toluene :acetic acid:water. Dry and visualize with anisaldehyde. Field collected scats could be identified by the bile acids pattern revealed by this specific technique and ,then, used as a source of information for distribution, density and food habits studies.
\end{abstract}

Key words: Thin layer chromatography, TLC, bile acids, felids, scats

Fecal bile acids and their relative concentrations follow patterns that are species specific (Haslewood 1967). This patterns, characterized by thin layer chromatography (TLC), have been used successfully to identify field collected scats of different species (Linx rufus, Canis latrans, Procyon lotor and Vulpes vulpes (Major et al. 1980); Felis concolor and Lutra canadensis (Johnson et al., 1982); and Felis concolor and F. rufus (Johnson et al., 1984). They were used to confirm scat identifications made by physical characteristics like size, shape, color and odor, that most times are uncertain.

We were interested in using these bile acid profiles to differentiate neotropical felid scats, because they contain small concentrations of bile acids, and it was necessary to develop a technique for extracting and visualizing them by TLC, as proposed by several authors (Eneroth 1963, Kritchevsky et al. 1963, Roscoe \& Fahrenbach 1963, Chávez 1979, Major et al. 1980 and Wardas \& Jedrzejczak 1995).

The purpose of the present work was develop a simple and relatively inexpensive technique for scat analysis, to aid in identifying field collected scats.

Scats were obtained from four Zoological Parks and three Wildlife Stations. We had scats from: six mountain lions (Puma concolor), six jaguars (Panthera onca), seven geoffrogy's cats (Felis geoffrogy), two jaguarundis (Herpaulurus jaguaroundi), one margay (Leopardus wiedii), two ocelots (Leopardus pardalis) and two 
pampas cats (Felis colocolo). All of them were fed basically with meat, so we did not expect to find plant pigments interfering with the bile acids.

Fresh feces were dried at room temperature, pulverized with a mortar and pestle, and stored in closed bottles. One $\mathrm{g}$ of pulverized sample was used to prepare bile acid solution. We tested several extracting procedures (Table 1). The sample bile acid fractions were stored in closed bottles, at room temperature and without light. When solvent evaporated, solutes were redissolved in $5 \mathrm{ml}$ of 1:1 benzene:methanol (V/V).

Seven known bile acids: cholic, quenodeoxicholic, deoxicholic, dehydrocholic, taurocholic, taurodeoxicholic and glicocholic (prepared in $0.1 \%$ solution of ethanol) and cholesterol (prepared in $0.1 \%$ solution of chloroform), were used as standards during the experiment, to recognize bands from the sample extracts. Sample extracts and standards were spotted $1 \mathrm{~cm}$ apart, on glass plates of 20x50 $\mathrm{cm}$, coated with a $250 \mu \mathrm{m}$ thick layer of silicagel H or G60 Merk (prepared in the laboratory, activated by drying them for one hour at 100 ${ }^{\circ} \mathrm{C}$ oven). We applied several amounts (15-60 $\mu 1)$ of each sample from each species, and of each standard, to find an acceptable amount, and cheking that the solvent dried between each spot. Plates were run in a developing bath (until the solvent front traveled $14 \mathrm{~cm}$ from the spotting line), air dried and sprayed with visualizing agent. We tried different developing-visualizing combinations (Table 2 ). In every case we used a 5\% (V/V) anisaldehyde alcoholic solution to prepare the visualizing system, and this was stored at $5-15^{\circ} \mathrm{C}$ to prevent oxidation, lasting invariable for about 15 days.

Plates were placed in a $120^{\circ} \mathrm{C}$ oven for about $20 \mathrm{~min}$.

We ran plates with extracts of the same sample prepared with the different procedures described above to compare them. We also compared the different developing-visualizing system combinations on the same extracts and standards, in order to find which one best separated and revealed the bands by TLC.
The Rf value (the distance traveled by a band divided by the distance traveled by the solvent front, measured with a $0.05 \mathrm{~mm}$ precision caliper) was calculated for each observed band. Also, color, and intensity and size of each band (related to the steroid's concentration ) were recorded. In order to quantify variation in the TLC results, we run several plates of the same sample extracts and standards, and of different samples of the same species, using the selected technique.

Plates were analyzed immediately because oxidation changes color and some bands disappear with time. When it was possible, we photographed the plates.

\section{RESULTS}

Of the procedures for bile acid extraction that were tested, $\mathrm{N}^{\circ} 3$ was the most satisfactory. Technique $\mathrm{N}^{\mathrm{o}} 1$ was rejected because, although it could separate the same products, it was more expensive and required more work than others. Extracts obtained with absolute ethanol (in cold or heat), and with technique $\mathrm{N}^{\circ} 9$, reveled fewer spots on the TLC plates, using different developing-visualizing systems.

No differences were observed in the number of bands separated from the same sample when using activated charcoal in the extraction procedure, as specified by Johnson et al. 1981.

We found that $40 \mu \mathrm{l}$ was the appropriate amount of extract to be spotted in the plates. We observed that glicocholic and dehydrocholic acid's bands were not visualized if we spotted quantities of $10 \mu \mathrm{l}$.

The best results were obtained when using G60 Merk silicagel on the plates.

Among developing-visualizing systems, combination $\mathrm{N}^{\circ} 10$ gave the best results regarding sharpness, coloring and number of bands developed. Other combinations revealed monochromatic bands or did not separate them all. Visualizing agents containing sulfuric acid developed very dark monochromatic bands. 
TABLE 1

Extraction techniques to prepare the bile acid solutions

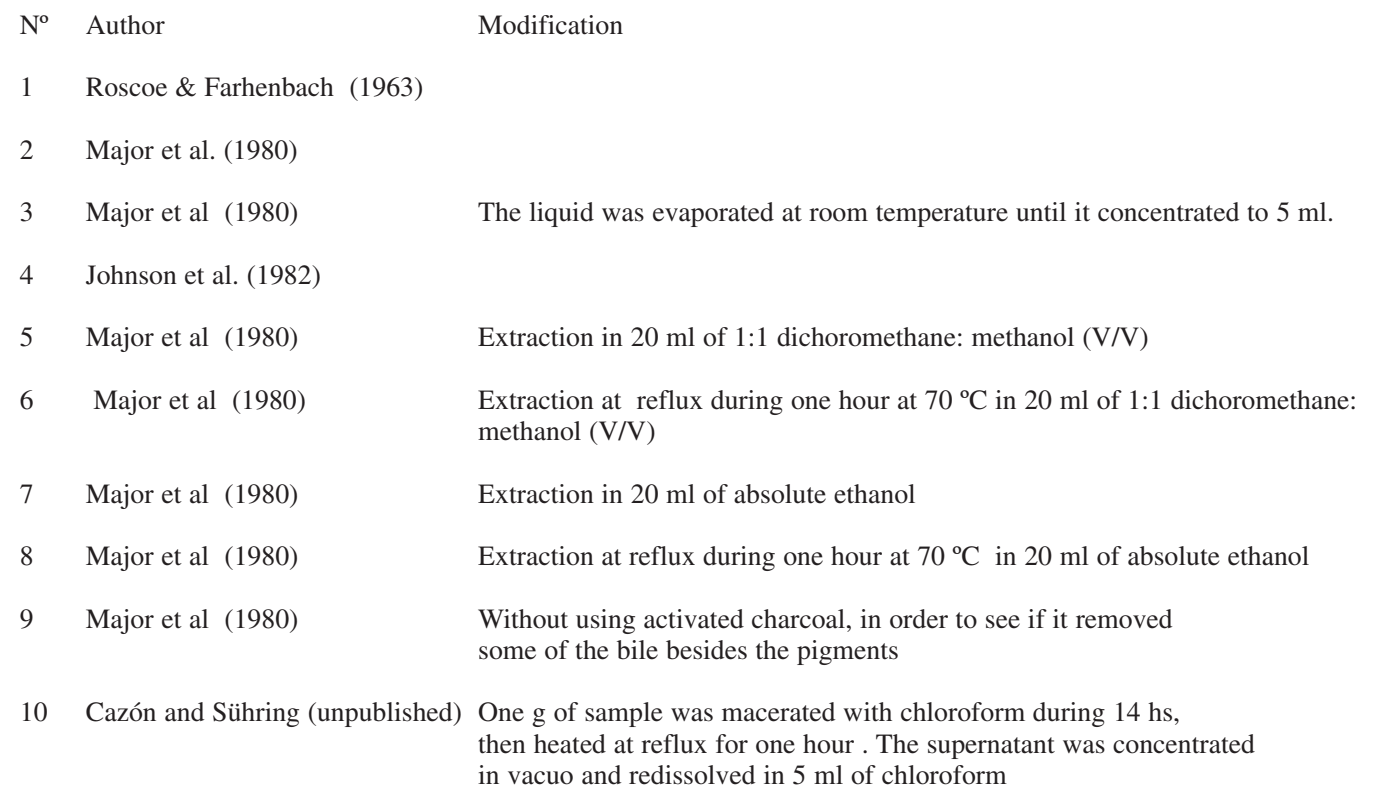

All bands were not present in every species profile. Intensity and size of the same band differed between some species.

Means and standard deviations of Rf values measured for each standard, as well as color, are shown in Table 3.

\section{DISCUSSION}

TLC of fecal bile acids is a biochemical technique that has been used to identify scats of different species. Innovated procedure for analyzing felid's feces is: 1) $1 \mathrm{~g}$ of dry pulverized feces, 2) shake for $3 \mathrm{hr}$ at room temperature in $20 \mathrm{ml} \mathrm{1:1}$ benzene : methanol, 3) filter and evaporate to $5 \mathrm{ml}, 4$ ) spot $40 \mu \mathrm{l}$ on silica Gel G60 TLC plate, 5) develop in (5:5:1.5) toluene :acetic acid:water, 6) air dry and visualize with $(0.5: 50: 1)$ anisaldehyde: glacial acetic acid:concentrated sulfuric acid.
It is the best technique regarding extraction, separation and differentiation of steroids, even by color and intensity of their respective bands. With it we detected variation among TLC plates: 1) Variations in intensity and size of a band of the same extract reflect the evenness of the visualizing spray. A glass atomizer using pressed air should be use to propel the reagent. 2) Variation in the Rf values for the same band on the same plate was probably caused by non uniformity in silicagel layer's thick. We suggest the use of glass or aluminum support plates. 3) All bands were not present in every sample of the same species, probably because of slight differences in the diet complement. Even so, this variation had minor effects on the bile acid profiles.

Sample extracts should always be run with standards to guarantee correct identification of the bands. Bile acids visualization may vary due to changes in the TLC procedure, so it 
TABLE 2

Different developing-visualizing agent system combinations

Developing mixture

1 Petcoff 's solution (hexane:methylethylketone: acetic acid (56:36:8), Chavez (1979)

2 Petcoff 's solution solution (Chávez 1979)

3 Petcoff 's solution solution

4 toluene:acetic acid:water (5:5:1), as reported by Roscoe \& Fahrenbach (1963)

5 toluene:acetic acid:water $(5: 5: 1)$

6 toluene:acetic acid:water (5:5:1)

7 toluene:acetic acid:water $(25: 25: 1.5)$, as reported by Wardas \& Jedrzejczak (1995)

8 cloroform:methanol:acetic acid (80:12:3)

9 hexane:aketone (7:3)

10 toluene:acetic acid:water (5:5:1.5)

must be performed conscientiously. Many scats from each animal, and many animals from each species, must be analyzed to quantificate individual and specific variation. Several trials must be made before defining the fecal bile acids pattern for each species.

Although many similarities occurred between bile acids profiles of the seven species we studied, there are no two identical profiles. When possible, visual characteristics of feces should be used to corroborate identification. With reliable identification, scats are a source of information for distribution, density and food habits studies.
Visualizing agent

$20 \%$ sulphuric acid in ethanol

$50 \%$ sulphuric acid solution

Anisaldehyde: glacial acetic acid: conc. sulphuric acid (0.5:50:1), as reported by Kritchevsky et al. (1963)

$20 \%$ sulphuric acid in ethanol

$50 \%$ sulphuric acid solution (this combination was used by Roscoe \& Fahrenbach 1963)

Anisaldehyde: glacial acetic acid: concentrated sulphuric acid (0.5:50:1) (Kritchevsky et al. 1963)

Anisaldehyde: glacial acetic acid:concentrated sulphuric acid (0.5:50:1) (Kritchevsky et al. 1963)

$10 \%$ phosphomolibdic acid in ethanol (Siegfried and Elliott 1968).

Anisaldehyde: glacial acetic acid:concentrated sulphuric acid (0.5:50:1) (Kritchevsky et al. 1963)

Anisaldehyde: glacial acetic acid:concentrated sulphuric acid (0.5:50:1), (Kritchevsky et al. 1963)

\section{ACKNOWLEDGMENTS}

This project was supported by the Consejo de Investigación de la Universidad Nacional de Salta.

\section{RESUMEN}

Los patrones de ácidos biliares fecales han sido utilizados satisfactoriamente para identificar heces. Las heces de félidos neotropicales son propicias para ser identificadas bioquímicamente, ya que contienen baja concentración de pigmentos vegetales que pudieran interferir en la detección de ácidos biliares. Sin embargo los ácidos bi- 
TABLE 3

Mean and standard deviations (SD) of Rf values for each steroid used as standards in the TLC plates and color for each steroid

$\begin{array}{lllll}\text { Standards } & \text { Color } & \mathrm{R}_{\mathrm{f}} \text { mean } & \mathrm{R}_{\mathrm{f}} \mathrm{SD} & \mathrm{n} \\ \text { Cholic Acid } & \text { Yellowish ligth brown } & 0.139 & 0.046 & 18 \\ \text { Deoxicholic Acid } & \text { Yellowish ligther brown } & 0.358 & 0.068 & 19 \\ \text { Dehidrocholic Acid } & \text { Bright yellow } & 0.360 & 0.057 & 9 \\ \text { Taurocholic Acid } & \text { Brown } & 0.136 & 0.042 & 8 \\ \text { Taurodeoxicholic acid } & \text { Greenish brown } & 0.105 & 0.046 & 9 \\ \text { Glycokenodeoxicholic acid } & \text { Grey-brown } & 0.062 & 0.017 & 2 \\ \text { Glycocholic acid } & \text { Brown } & 0.116 & 0.117 & 8 \\ \text { Cholesterol } & \text { Violet } & 0.625 & 0.050 & 11\end{array}$

$(\mathrm{n}=$ number of data used in the calculations $)$

liares se encuentran en bajas concentraciones en las heces, por lo cual desarrollamos en este trabajo una técnica apropiada para su extracción, visualización y determinación. Veintiocho heces de diferentes félidos recolectadas de Zoológicos y Estaciones de Fauna Silvestre fueron secadas y pulverizadas. El procedimiento para analizar las heces es: Tomar un gramo de feca pulverizada y agitar en $20 \mathrm{ml}$ de benceno:metanol a temperatura ambiente durante $3 \mathrm{hr}$; luego filtrar y evaporar hasta $5 \mathrm{ml}$. Sembrar en placa de TLC y desarrollar en tolueno:ác. acético:agua. Secar y revelar con anisaldehído. Las heces recolectadas en el campo podrían ser identificadas a través de los patrones de ácidos biliares evidenciados con esta técnica específica, y ser entonces utilizadas como fuente de información en estudios sobre distribución, densidad y hábito alimenticio.

\section{REFERENCES}

Chavez, M. N. 1979. Thin-layer chromatographic separation of keto derivatives of free bile acids. J. Chromatogr. 162: 71-75.

Eneroth, P. 1963. Thin-layer chromatography of bile acids. J. Lipid Res. 4 : 11-16.

Haslewood, G. A. D. 1967. Bile salt evolution. J. Lipid Res. 8: 535- 550.

Johnson, M. K., D. R. Aldred, E. W. Clinite, \& M. J. Kutilek. 1981. Biochemical Identification of bobcat scats. In: Proc. Bobcat Res. Conf. Nat. Wildl. Fed. Sci. \&Tech. Ser. 6: 92 -96.
Johnson, M. K., D. R. Aldred \& T. E. Martin. 1982. Feces bile acids and furbearers. The Worldwide Furbearer Conf. Procedings $1143-1150$.

Johnson, M. K., R. C. Belden \& D. R. Aldred.1984. Differentiating mountain lion and bobcat scats. J. Wildl. Manage. 48: 239 - 244

Kritchevsky, D., D. S. Martak \& G. H. Rothblat. 1963. Detection of Bile Acids in Thin-layer Chromatography. Anal. Biochem. 5: 388-392.

Major, M., M. K. Johnson, W. Shaw Davis \& T. F. Kellogg. 1980. Identifying scats by recovery of bile acids. J. Wildl. Manage. 44 : 290293.

Quinn, T. \& W. R. Jackman. 1994. Influence of diet on detection of fecal bile acids by thin-layer chromatography. J. Wildl. Manage. 58 : 295 299.

Roscoe, H. G \& M. J. Fahrenbach. 1963. Removal of fecal pigments and its application to the determination of fecal bile acids in the rat. Anal. Biochem. 6: $520-529$.

Siegfried, C. M \& W. H. Elliott. 1968. Separation of bile acid of rat bile by thin-layer chromatography. J. Lipid Res. 9: 294 - 295.

Wardas, W. \& M. Jedrzejczak. 1995. New Visualizing Agents for Bile Acids in TLC. Chem. Anal. 40: 73- 79 . 